\title{
Customer Incentives for Energy Efficiency Through Program Offerings
}

\author{
A RESOURCE OF THE NATIONAL ACTION PLAN FOR \\ ENERGY EFFICIENCY
}

FEBRUARY 2010 
The Leadership Group of the National Action Plan for Energy Efficiency is committed to taking action to increase investment in cost-effective energy efficiency. Customer Incentives for Energy Efficiency Through Program Offerings was developed under the guidance of and with input from the Leadership Group. The document does not necessarily represent a consensus view and does not represent an endorsement by the organizations of Leadership Group members.

Customer Incentives for Energy Efficiency Through Program Offerings is a product of the National Action Plan for Energy Efficiency and does not reflect the views, policies, or otherwise of the federal government. The role of the U.S. Department of Energy and U.S. Environmental Protection Agency is limited to facilitation of the Action Plan.

If this document is referenced, it should be cited as:

National Action Plan for Energy Efficiency (2010). Customer Incentives for Energy Efficiency Through Program Offerings. Prepared by William Prindle, ICF International, Inc. <www.epa.gov/eeactionplan>

\section{For More Information}

Regarding Customer Incentives for Energy Efficiency Through Program Offerings, please contact:

\section{Stacy Angel}

U.S. Environmental Protection Agency

Office of Air and Radiation

Climate Protection Partnerships Division

Tel: (202) 343-9606

E-mail: angel.stacy@epa.gov

Regarding the National Action Plan for Energy Efficiency, please contact:

Stacy Angel

U.S. Environmental Protection Agency

Office of Air and Radiation

Climate Protection Partnerships Division

Tel: (202) 343-9606

E-mail: angel.stacy@epa.gov
Larry Mansueti

U.S. Department of Energy

Office of Electricity Delivery and Energy Reliability

Tel: (202) 586-2588

E-mail: lawrence.mansueti@hq.doe.gov 


\section{Table of Contents}

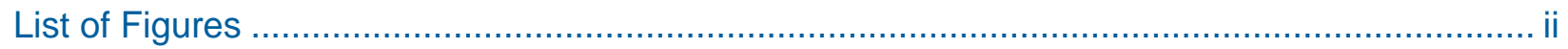

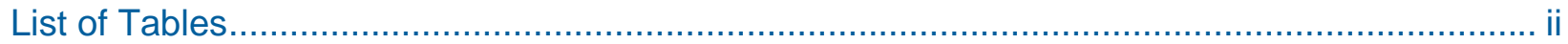

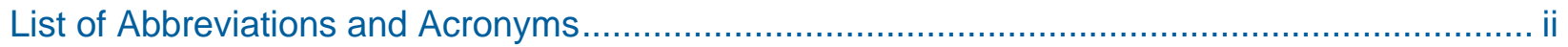

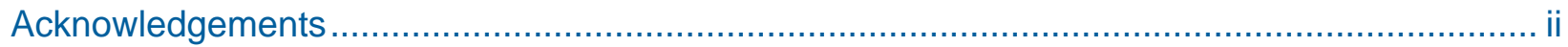

Executive Summary ...................................................................................... 1

Customer Incentives for Energy Efficiency Through Programs ...................................... 1

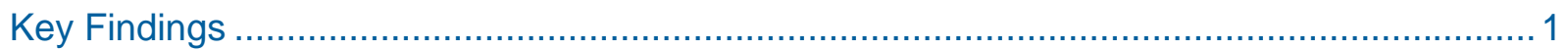

Key Questions to Ask Regarding Customer Incentives in Program Design........................... 3

Achieving All Cost-Effective Energy Efficiency_A Vision for 2025 ................................... 4

Customer Incentives for Energy Efficiency Through Program Offerings ............... 5

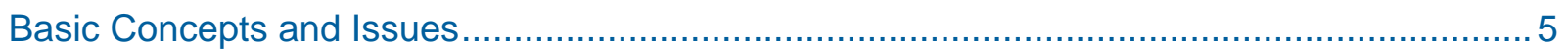

Program Theory and Design: The Basis for Efficiency Program Incentives .......................... 8

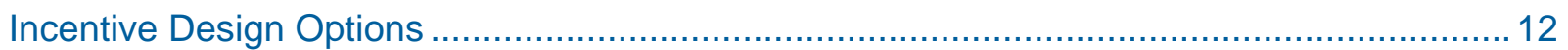

Program Experience: Summary of Incentives Offered in Best-Practice Programs ................ 17

Considerations in Reviewing, Designing, and Implementing Program Incentives ................. 25

Key Questions to Ask Regarding Customer Incentives in Program Design.......................... 26

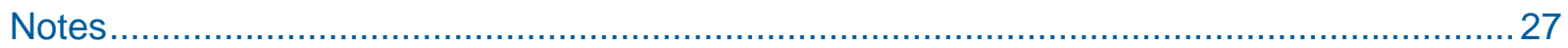

Appendix A: National Action Plan for Energy Efficiency Leadership Group...... A-1

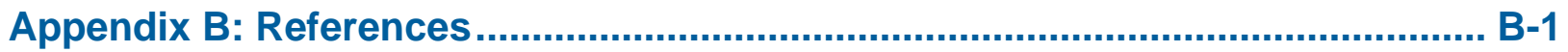




\section{List of Figures}

Figure 1. Overview of Energy Efficiency Incentive Types 2

\section{List of Tables}

Table 1. Incentive Types and Levels of Market Intervention. 7

Table 2. Illustrative Program Theory Examples: Key Stakeholders, Barriers, and Program Strategies by Customer Segment

Table 3. Comparative Impacts of Incentive Types

Table 4. Summary of Incentives Offered in Current Programs

\section{List of Abbreviations and Acronyms}

$\begin{array}{ll}\text { ARRA } & \text { American Recovery and Reinvestment Act of } 2009 \\ \text { CFL } & \text { compact fluorescent lamp } \\ \text { DOE } & \text { U.S. Department of Energy } \\ \text { EPA } & \text { U.S. Environmental Protection Agency } \\ \text { HVAC } & \text { heating, ventilation, and air conditioning } \\ \text { LED } & \text { light-emitting diode } \\ \text { LIHEAP } & \text { Low-Income Home Energy Assistance Program } \\ \text { NGO } & \text { nongovernmental organization } \\ \text { WAP } & \text { Weatherization Assistance Program }\end{array}$

\section{Acknowledgements}

This brief, Customer Incentives for Energy Efficiency Through Program Offerings, is a key product of the Year Four Work Plan for the National Action Plan for Energy Efficiency. This work plan was developed based on Action Plan Leadership Group discussions and feedback expressed during and in response to the January 2009 Leadership Group Meeting. A full list of Leadership Group members is provided in Appendix A and at www.epa.gov/eeactionplan.

With direction and comment by the Action Plan Leadership Group, the paper was developed by Bill Prindle of ICF International, Inc. Rich Sedano of the Regulatory Assistance Project and Alison Silverstein of Alison Silverstein Consulting provided their expertise during review and editing of the brief.

The U.S. Environmental Protection Agency (EPA) and the U.S. Department of Energy (DOE) facilitate the National Action Plan for Energy Efficiency. Key staff include Larry Mansueti (DOE Office of Electricity Delivery and Energy Reliability), Kathleen Hogan and Katrina Pielli (DOE Office of Energy Efficiency and Renewable Energy), and Stacy Angel and Maureen McNamara (EPA Climate Protection Partnerships Division).

Eastern Research Group, Inc., provided copyediting and production services. 


\section{Executive Summary}

This brief, Customer Incentives for Energy Efficiency Through Program Offerings, summarizes the approaches used by energy efficiency program administrators when assessing incentives to be used in energy efficiency programs. The scope of this brief is limited to financial incentives and services offered through public policy-driven programs aimed primarily at utility customers. It is provided as part of a comprehensive suite of papers and tools to assist organizations in meeting the National Action Plan for Energy Efficiency goal of achieving all cost-effective energy efficiency by 2025.

Improving energy efficiency in our homes, businesses, schools, governments, and industrieswhich consume more than 70 percent of the natural gas and electricity used in the country-is one of the most constructive, cost-effective ways to address the challenges of high energy prices, energy security, air pollution, and global climate change. Despite these benefits and proven approaches, energy efficiency remains critically underutilized in the nation's energy portfolio. Regulators can address this problem in part by removing one of the persistent barriers to energy efficiency by creating effective customer incentives for energy efficiency through program offerings.

\section{Customer Incentives for Energy Efficiency Through Programs}

Energy efficiency programs provide a range of financial and other incentives to encourage investments in energy-efficient technologies, related services, and/or behavior change. These incentives range from simple cash rebates for the purchase of efficient products to bundled customized financial incentives and technical assistance. Incentives can be targeted to individual customers and purchase transactions, or can be directed further upstream in market supply chains to encourage manufacturers, retailers, or contractors to affect how customers choose products, building designs, or building operating methods. An overview of incentive types is provided in Figure 1, with further discussion provided in the brief.

\section{Key Findings}

- Most efficiency programs have used direct financial incentives—rebates and other forms of direct subsidy for individual customers and transactions.

- Incentives are also commonly directed to upstream and midstream channel partners or trade allies such as retailers, contractors, manufacturers, and distributors.

- Incentives can be used in conjunction with other program strategies to achieve market transformation, whereby there is a lasting change in the availability and demand for energy-efficient goods and services.

- Managing efficiency programs through portfolios allows program administrators to match incentive types and program features to different customer types and market needs. Portfolios can evolve over time, from simpler and fewer incentive types early on to more feature-rich and diverse incentives and services later on.

- Program administrators meeting aggressive energy savings targets are "pushing the envelope" of incentive and program design, providing bundled sets of financial incentives 
and other services designed to obtain deeper savings per customer and produce wider and longer-lasting market effects.

- Some markets continue to be appropriate for simple, direct incentive approaches.

- New research and program pilots are underway to better understand emerging, innovative incentive approaches, including whole-building performance-based incentives and incentives designed to change customer behavior and decision-making, beyond targeting product purchase transactions.

\section{Figure 1. Overview of Energy Efficiency Incentive Types}

\section{Types of Program Incentives}

Financial Incentives

- Rebates (prescriptive, custom)

- Discounts (purchase, energy bill)

- Financing (rate reductions, on-bill)
Non-Financial Incentives

- Support services

- Technical assistance

- Education and training

- Information sharing

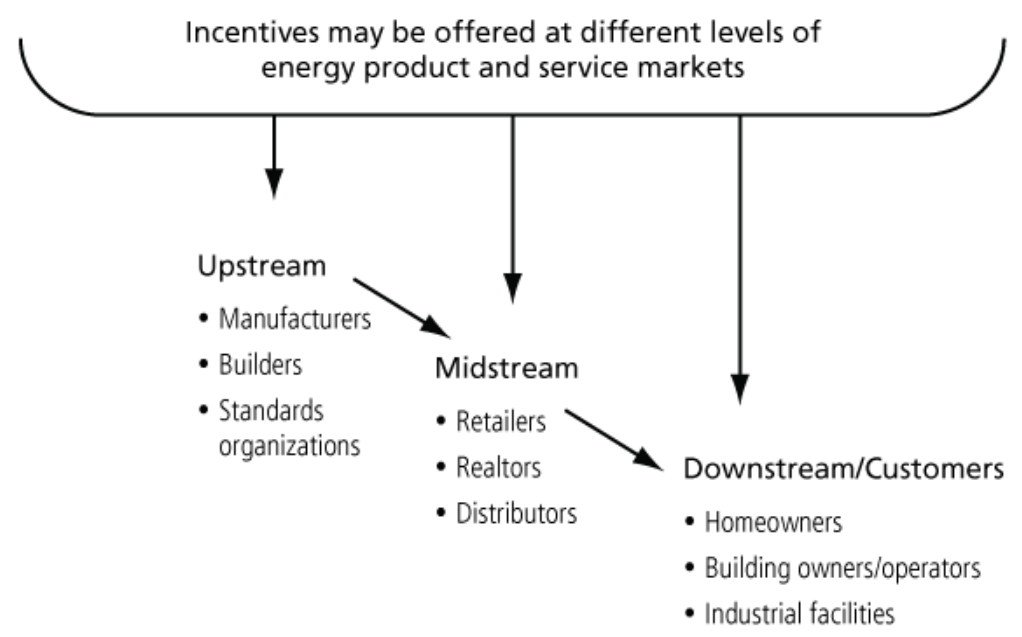




\section{Key Questions to Ask Regarding Customer Incentives in Program Design}

When reviewing program plans, asking the following questions can help get at the key issues that can make a difference between successful and unsuccessful offerings:

- Are the incentives and other program strategies based on a clear, logical program theory that identifies barriers in the target market and designs incentives and other strategies to reduce those barriers?

- Is the program theory based on, and validated by, a detailed market assessment that examines key market actors and decision-making processes?

- Is the program part of a wider portfolio of energy efficiency programs, and if so does it provide appropriate incentives within the portfolio's context? Are incentive levels and other services appropriate for the developmental cycle of the program and the wider portfolio?

- Does the program design consider and seek to leverage other incentive options, such as federal, state, or local tax incentives, or other programs or services?

- Are incentives and other program strategies proven to be effective elsewhere? Has the program designer provided solid evidence of its success in other markets?

- Are incentive and other program strategies appropriate to the climate, customer mix, and local market characteristics?

- Did program designers consult customers and trade allies in designing incentives and other program features?

- Are customer incentives part of a complete program plan, including infrastructure development, marketing, and program implementation and evaluation?

- What may be the unintended consequences of providing the incentives? Can program strategies be designed to reduce any potential negative consequences?

- Is the proposed program or portfolio cost-effective when applying the jurisdiction's applicable cost-effectiveness tests? 


\section{Achieving All Cost-Effective Energy Efficiency-A Vision for 2025}

This brief has been developed to help parties pursue the key policy recommendations of the National Action Plan for Energy Efficiency and its Vision for 2025 implementation goals. It directly supports Vision Implementation Goal Five, which encourages program regulators and administrators to establish effective energy efficiency delivery mechanisms.

Within this context, state public utility commissions, publicly governed utility boards, public energy agencies, independent third-party administrators, and utility companies are encouraged to consider how the financial incentives and related services they provide to customers can be part of the comprehensive solution to energy efficiency. For information on the full suite of policy and programmatic options to remove barriers to energy efficiency, see the Vision for 2025 and other Action Plan resources available at www.epa.gov/eeactionplan. 


\section{Customer Incentives for Energy Efficiency Through Program Offerings}

This brief summarizes 20-plus years of U.S. experience with energy efficiency programs offering incentives to utility customers. This experience spans the majority of states, as well as a range of customer end-use markets, incentive types, and associated program services. This brief seeks to distill best practices for the principal customer markets and incentive types, and also seeks to examine current trends in effective bundling of incentives with other services for targeted markets. Discussed are:

- Basic concepts and issues to help explain incentive types and how they are used

- The use of program theory to assist in designing customer incentives

- Examples of how incentives are applied in different market and program settings

- Experience from the field

- Guidance on key implementation issues

This brief does not go into detail on specific program examples or broader energy efficiency program issues, nor does it address regulatory issues such as cost-effectiveness, cost recovery, or shareholder incentives, except as they affect incentive or program design. These issues are addressed in other Action Plan documents. ${ }^{1}$ The rates customers pay for electricity and gas supply also motivate customers to change their energy use, which is addressed in an Action Plan brief titled Customer Incentives for Energy Efficiency Through Electric and Natural Gas Rate Design (National Action Plan for Energy Efficiency, 2009).

\section{Basic Concepts and Issues}

This section provides definitions and a conceptual overview of the context for customer energy efficiency incentives. For the purposes of this brief, the term "customer energy efficiency incentive" refers to an offering from an efficiency program administrator intended to encourage or motivate customers to reduce the total amount of energy they consume for a given level of energy service provided, without compromising the quality or level of service. Resulting energy efficiency actions could be investments in energy-efficient technologies and practices and/or changes in customer behavior. The terms "motivate," "encourage," and "incent" may be used interchangeably. Other key terms used in this brief are defined as follows:

- Direct incentives refer to direct payments or subsidies to individual customers for the purchase or installation of a specific energy efficiency measure. Examples include:

- Rebates. A rebate is a payment from the program sponsor to an individual customer, typically made after a qualified item is purchased and a rebate coupon or application is submitted. Rebates can be prescriptive (fixed amounts pre-defined for specific products) or custom (defined by formulas or other rules that match the payment to a specific product or project).

- Discounts. Discounts can be viewed as "instant" or upfront rebates, taken off the price of the product at the point of purchase. Discounts can also be structured as reductions or credits on energy bills rather than at the point of purchase. 
- Financing. Offering financing such as loans to customers through the program can be an incentive to implement efficiency measures, especially for customers who may not easily qualify for conventional financing. But financing also introduces other players and other issues for program designers and operators, and should thus be undertaken with all due consideration. Incentives can also be added into financing through interest rate reductions (which can be achieved through public-purpose bonds or other mechanisms), flexible terms such as extended payment periods, and the convenience of payment through utility bills or performance contracting.

- Upstream/midstream incentives are financial incentives that involve payments to parties that are "up the supply chain" from the individual customer purchase transaction. Upstream incentives reach relatively far up the supply chain, typically to manufacturers; midstream incentives are targeted closer to the customer end of the market, typically to retailers or installation contractors. Upstream/midstream incentives can affect larger markets than direct incentives targeted to individual customers, because upstream and midstream players are able to offer the desired products or services to all the customers they serve, not just those who learn about direct customer rebates.

- This brief also addresses non-financial incentives, which may include:

- Technical services. The many steps involved in identifying, developing, installing, and paying for efficiency improvements can create transaction-cost barriers, sometimes referred to as the "hassle factor." Typical homeowners and business owners do not have the time and expertise to work through all these steps, and thus many worthy projects succumb to the "hassle factor." Program services that help customers through this process can reduce the hassle and increase the installation rate. Some customers may know what they would like to do, but do not have the expertise to design or evaluate the project. Technical services can help customers bring an efficiency idea to fruition by developing the specifications needed to implement the project, as well as identifying the benefits and costs.

- Information services. Many customers lack basic information on how efficient they are, what their options might be, and how to implement those options. Information services can reduce this chronic lack of information and guidance through training focused on particular skills or technology issues. Training can take many forms, from teaching sales staff to understand and sell the benefits of efficient products, to training building operators to run their buildings efficiently, and training building designers to use simulation software to evaluate efficient building designs.

- Non-financial incentives/services may be bundled with direct or indirect incentives, or may be offered on a stand-alone basis. Depending on the customer type and market characteristics that a given program targets, an effective energy efficiency program design may include any one of these incentive types, or may bundle them together in various ways.

Table 1 provides a simplified visual framework of incentive types, market intervention levels, and examples. 
Table 1. Incentive Types and Levels of Market Intervention

\begin{tabular}{|c|c|c|c|}
\hline \multirow{2}{*}{ Incentive Type } & \multicolumn{3}{|c|}{ Level of Market Intervention } \\
\hline & Upstream & Midstream & Downstream \\
\hline $\begin{array}{l}\text { Financial } \\
\text { - } \quad \text { Cash rebates } \\
\text { - } \quad \text { Discounts } \\
\text { - } \quad \text { Financing } \\
\text { - } \quad \text { Tax credits }\end{array}$ & $\begin{array}{l}\text { Example: Cash } \\
\text { payment to } \\
\text { manufacturers for } \\
\text { making products that } \\
\text { meet high-efficiency } \\
\text { performance criteria }\end{array}$ & $\begin{array}{l}\text { Example: Cash } \\
\text { payments to retailers } \\
\text { for promoting/ } \\
\text { discounting high- } \\
\text { efficiency products }\end{array}$ & $\begin{array}{l}\text { Example: Cash } \\
\text { rebate to customers } \\
\text { who purchase } \\
\text { efficient products }\end{array}$ \\
\hline $\begin{array}{l}\text { Non-Financial } \\
\text { - } \quad \text { Technical } \\
\text { services } \\
\text { - Information } \\
\text { services }\end{array}$ & $\begin{array}{l}\text { Example: Providing } \\
\text { technical assistance } \\
\text { to builders and } \\
\text { developers to design } \\
\text { buildings for high } \\
\text { energy performance }\end{array}$ & $\begin{array}{l}\text { Example: Providing } \\
\text { point-of-purchase } \\
\text { displays and } \\
\text { information materials } \\
\text { to support retailer } \\
\text { promotions of high- } \\
\text { efficiency products }\end{array}$ & $\begin{array}{l}\text { Example: Helping } \\
\text { customers develop } \\
\text { efficiency projects, } \\
\text { arrange installation, } \\
\text { and ensure quality } \\
\text { control }\end{array}$ \\
\hline $\begin{array}{l}\text { Bundled Incentives } \\
\text { and Services } \\
\text { - Combinations of } \\
\text { financial and non- } \\
\text { financial } \\
\text { incentives }\end{array}$ & $\begin{array}{l}\text { Example: Offering } \\
\text { builders/developers } \\
\text { both design } \\
\text { incentives and cash } \\
\text { rebates for building } \\
\text { high-efficiency } \\
\text { buildings }\end{array}$ & $\begin{array}{l}\text { Example: Offering } \\
\text { retailers cash } \\
\text { incentives and } \\
\text { providing training for } \\
\text { sales staff }\end{array}$ & $\begin{array}{l}\text { Example: Providing } \\
\text { design assistance to } \\
\text { develop customer } \\
\text { projects, arranging } \\
\text { financing, and } \\
\text { subsidizing interest } \\
\text { rates }\end{array}$ \\
\hline
\end{tabular}

Incentive designs and levels often vary from program to program, sometimes raising questions among regulators or other stakeholders. To understand the reasons why incentives may differ between programs and markets, and may change over time, it is helpful to view programs within the context of the larger portfolio of energy efficiency programs.

Leading program administrators around the country design portfolios to address all customer types, to anticipate system needs, to manage performance risk, and to ensure a pipeline of program savings in both the near and longer term. ${ }^{2}$ As a result, when looking across a portfolio, the type and magnitude of incentives may differ, based on the market barriers and other characteristics of each market. For example, low-income customers lack time and money for implementing efficiency measures, so a direct installation approach may be used and covering the full cost of the measures may be justified. For other residential customers, a mass-market approach may be used and only a portion of the incremental costs for buying and installing similar measures would be covered by utility incentives.

A program portfolio approach also includes a time dimension. Initially, incentive levels may need to be higher to attract the attention of suppliers and customers, but as programs and markets mature, incentive levels for particular technologies may need to be adjusted downward, focused on higher efficiency levels, or eliminated altogether. Similarly, within a portfolio of programs, it is increasingly important to include more complex programs aimed at achieving deeper savings in homes, buildings, and industrial facilities. Initially, these more complex programs may deliver a small portion of a portfolio-wide savings, but over time as program infrastructure is built, they 
ramp up to help achieve more aggressive goals or fill in a gap left by programs that have matured and been discontinued.

Keeping in mind both of these dimensions of the larger program portfolio-the market segmentation dimension and the time dimension-can help avoid confusion about the differences among incentive designs or levels.

\section{Program Theory and Design: The Basis for Efficiency Program Incentives}

Program designers use program theory to help determine the best mix of incentives and other strategies to deploy in a program. Program theory involves identifying the key market actors involved (e.g., manufacturers, distributors, customers) in delivering the targeted energy-efficient goods or services, the market barriers each of these players faces in trying to sell or procure the good, and the strategies that can be used to best influence them (see Table 2 for illustrative examples). Program theory can also identify helpful metrics to track in order to determine whether program strategies are working as anticipated (e.g., number of participating suppliers, number of rebates fulfilled).

Table 2. Illustrative Program Theory Examples: Key Stakeholders, Barriers, and Program Strategies by Customer Segment

\begin{tabular}{|c|c|c|c|}
\hline $\begin{array}{l}\text { Customer } \\
\text { Segment }\end{array}$ & Key Stakeholders & Key Program Barriers & $\begin{array}{c}\text { Key Program } \\
\text { Strategies }\end{array}$ \\
\hline $\begin{array}{l}\text { Large } \\
\text { Commercial } \\
\text { and } \\
\text { Industrial } \\
\text { Retrofit }\end{array}$ & $\begin{array}{l}\text { Contractors } \\
\text { - } \text { Building owners and } \\
\text { operators } \\
\text { Distributors: lighting, } \\
\text { HVAC, motors, other } \\
\text { - Product } \\
\text { manufacturers } \\
\text { - Engineers } \\
\text { - Energy service } \\
\text { companies }\end{array}$ & $\begin{array}{l}\text { - } \text { Access to capital } \\
\text { - } \quad \text { Competing priorities } \\
\text { - } \quad \text { Lack of information } \\
\text { Short-term payback } \\
\text { (under two years) } \\
\text { mentality }\end{array}$ & $\begin{array}{ll}\text { - } & \begin{array}{l}\text { Financial incentives } \\
\text { (rebates) }\end{array} \\
\text { - } & \text { Performance } \\
\text { contracting } \\
\text { - } & \text { Performance } \\
\text { benchmarking } \\
\text { - } & \text { Partnership with } \\
\text { ENERGY STAR } & \text { - } \\
\text { Low-interest } \\
\text { financing } \\
\text { Information from } \\
\text { unbiased sources } \\
\text { - } \quad \text { Technical assistance } \\
\text { Operations and } \\
\text { maintenance training }\end{array}$ \\
\hline $\begin{array}{l}\text { Small } \\
\text { Commercial }\end{array}$ & $\begin{array}{l}\text { Distributors: lighting, } \\
\text { HVAC, other } \\
\text { Building owners } \\
\text { - } \quad \text { Business owners } \\
\text { Local independent } \\
\text { trades }\end{array}$ & $\begin{array}{l}\text { - } \text { Access to capital } \\
\text { - } \quad \text { Competing priorities } \\
\text { - } \quad \text { Lack of information }\end{array}$ & $\begin{array}{ll}\text { - } & \begin{array}{l}\text { Financial incentives } \\
\text { (rebates) }\end{array} \\
\text { - } & \text { Information from } \\
\text { unbiased sources } \\
\text { - } & \text { Direct installation } \\
\text { - } & \text { Partnership with } \\
\text { ENERGY STAR }\end{array}$ \\
\hline
\end{tabular}




\begin{tabular}{|c|c|c|c|}
\hline $\begin{array}{l}\text { Customer } \\
\text { Segment }\end{array}$ & Key Stakeholders & Key Program Barriers & $\begin{array}{l}\text { Key Program } \\
\text { Strategies }\end{array}$ \\
\hline $\begin{array}{l}\text { Commercial } \\
\text { and } \\
\text { Industrial } \\
\text { New } \\
\text { Construction }\end{array}$ & $\begin{array}{l}\text { - Architects } \\
\text { - Engineers } \\
\text { - Building and energy } \\
\text { code officials } \\
\text { - Building owners } \\
\text { - Potential occupants }\end{array}$ & $\begin{array}{l}\text { Project/program } \\
\text { timing } \\
\text { - } \quad \text { Competing priorities } \\
\text { - Split incentives (for } \\
\text { rental property) } \\
\text { - } \quad \text { Lack of information } \\
\text { - Higher initial cost }\end{array}$ & $\begin{array}{l}\text { Early intervention (ID } \\
\text { requests for hookup) } \\
\text { - } \quad \text { Design assistance } \\
\text { Performance } \\
\text { targeting/ } \\
\text { benchmarking } \\
\text { - Partnership with } \\
\text { ENERGY STAR } \\
\text { Training of architects } \\
\text { and engineers } \\
\text { Visible and ongoing } \\
\text { presence in design } \\
\text { community } \\
\text { Education on life } \\
\text { cycle costs }\end{array}$ \\
\hline $\begin{array}{l}\text { Residential } \\
\text { Existing } \\
\text { Homes }\end{array}$ & $\begin{array}{l}\text { Distributors: } \\
\text { appliances, HVAC, } \\
\text { lighting } \\
\text { Retailers: appliance, } \\
\text { lighting, windows } \\
\text { Contractors: HVAC, } \\
\text { insulation, } \\
\text { remodeling } \\
\text { Homeowners }\end{array}$ & $\begin{array}{l}\text { - } \text { Higher initial cost } \\
\text { - } \quad \text { Lack of information } \\
\text { - } \quad \text { Competing priorities } \\
\text { Inexperience or prior } \\
\text { negative experience } \\
\text { with technology } \\
\text { (e.g., early compact } \\
\text { fluorescent lighting) } \\
\text { Emergency } \\
\text { replacements }\end{array}$ & $\begin{array}{l}\text { - } \text { Financial incentives } \\
\text { Partnership with } \\
\text { ENERGY STAR } \\
\text { Information on utility } \\
\text { Web sites, bill inserts, } \\
\text { and at retailers } \\
\text { Coordination with } \\
\text { retailers and } \\
\text { contractors }\end{array}$ \\
\hline $\begin{array}{l}\text { Residential } \\
\text { New Homes }\end{array}$ & $\begin{array}{ll}\text { - } & \text { Contractors: general } \\
\text { - } & \text { And HVAC } \\
\text { - } & \text { Code officials } \\
\text { - } & \text { Builders } \\
\text { - } & \text { Home buyers } \\
\text { - } & \text { Real estate agents } \\
\text { - } & \text { Financial institutions }\end{array}$ & $\begin{array}{l}\text { Higher initial cost } \\
\text { Split incentives: } \\
\text { builder is not the } \\
\text { occupant }\end{array}$ & $\begin{array}{l}\text { Partnership with } \\
\text { ENERGY STAR } \\
\text { - } \quad \text { Linking efficiency to } \\
\text { quality } \\
\text { - } \text { Working with builders } \\
\text { - } \text { Building code } \\
\text { education and } \\
\text { compliance } \\
\text { - Energy-efficient } \\
\text { mortgages }\end{array}$ \\
\hline
\end{tabular}




\begin{tabular}{|c|c|c|c|}
\hline $\begin{array}{l}\text { Customer } \\
\text { Segment }\end{array}$ & Key Stakeholders & Key Program Barriers & $\begin{array}{l}\text { Key Program } \\
\text { Strategies }\end{array}$ \\
\hline Multifamily & $\begin{array}{l}\text { Owners and } \\
\text { operators } \\
\text { - Contractors } \\
\text { - Code officials } \\
\text { - Tenants }\end{array}$ & $\begin{array}{l}\text { - Split incentives } \\
\text { - Lack of awareness }\end{array}$ & $\begin{array}{l}\text { - Financial incentives } \\
\text { Marketing through } \\
\text { owner and operator } \\
\text { associations }\end{array}$ \\
\hline Low Income & $\begin{array}{l}\text { Service providers: } \\
\text { WAP, LIHEAP } \\
\text { - Social service } \\
\text { providers: state and } \\
\text { local agencies } \\
\text { NGOs and advocacy } \\
\text { groups } \\
\text { Credit counseling } \\
\text { organizations } \\
\text { Tenants }\end{array}$ & 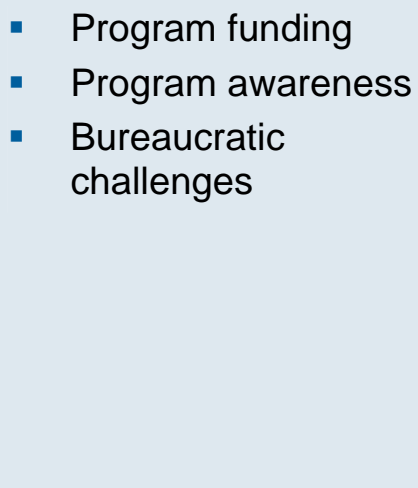 & $\begin{array}{l}\text { Consistent eligibility } \\
\text { requirements with } \\
\text { existing programs } \\
\text { - Direct installation } \\
\text { - Leveraging existing } \\
\text { customer channels } \\
\text { for promotion and } \\
\text { delivery } \\
\text { - Fuel-blind approach }\end{array}$ \\
\hline
\end{tabular}

Source: National Action Plan for Energy Efficiency (2006).

HVAC = heating, ventilation, and air conditioning;

LIHEAP = Low-Income Home Energy Assistance Program; NGO = nongovernmental organization;

WAP $=$ Weatherization Assistance Program

The program designer's goal is to develop the most effective and cost-effective mix of financial incentives, upstream incentives, and program services to address the barriers in each of the markets the program portfolio serves. Applying the program theory approach to the design process can be summarized (though oversimplified) in the following steps:

1. Define customer types. The most common approach in framing target markets is to segment customers by type, then identify the key market cycles in which customers' efficiency investment choices can best be influenced. Customer types are typically divided, at a minimum, between residential and non-residential customers. Within residential customers, low income customers are often identified as a customer group requiring unique approaches. Non-residential customers are then typically segmented into small commercial and large commercial/industrial. Some portfolios also segment industrial customers out from commercial customers. Depending on building size, efficiency improvements to multifamily residents may be targeted via residential or commercial programs. A complete program portfolio would normally seek to provide programs to all of these customer types.

2. Define market segments. For each customer type, typical cycles can be identified in which efficiency opportunities are largest and/or easiest to influence. These include new construction, especially for residential and commercial buildings; equipment replacement, or the market for replacing existing appliances and equipment as they wear out; and elective retrofit, which involves replacing or upgrading products, equipment, or appliances without regard to the replacement cycle. Efficient designs can be achieved at much lower capital costs than later retrofits, and some building energy 
features cannot realistically be altered via retrofits. New construction and equipment replacement markets are commonly referred to as "lost opportunity" markets, because these activities will occur whether or not the program influences them, and if the program does not influence them, efficiency opportunities can be lost, at least until the cycle renews itself. Because buildings typically remain in use for 50 to 100 years or more, and equipment can last 15 to 30 years, the energy impact of lost opportunities can be great, and thus program designers typically work hard to capture large shares of new construction and equipment replacement markets. ${ }^{3}$ Elective retrofit markets, because they have no pre-existing replacement cycles, require a different approach to incentive and program design. These programs often require higher incentive levels, and may entail more services to facilitate retrofit projects.

3. Identify key market barriers. The market definition process in steps 1 and 2 typically produces a set of broad target markets. The next step is to focus on the key actors involved in these markets and the key barriers that each market participant faces in supplying or procuring more efficient goods and services. Understanding market barriers entails understanding market actors, their key interests, and their decision-making processes. Because the literature on market barriers is extensive, this brief does not seek to recap it. ${ }^{4}$ There is no single set of consensus definitions for market barriers: for the purposes of this brief, we summarize barriers into structural, financial, and informational types.

- Structural barriers occur when certain parties in a market are not motivated or enabled to support energy efficiency policy goals, notably the "split-incentive" or "principal-agent" barrier. An example of this is when the tenant pays the energy bills and the landlord has little incentive to upgrade to efficient options.

- Financial barriers occur when the incremental cost of the efficient technology or practice is significantly higher than a standard efficiency counterpart. For example, if an efficient air conditioner costs $\$ 500$ more than a standard unit, most customers will choose the less expensive model.

- Informational barriers occur when customers or other market participants lack the information, expertise, or time to determine the most energy-efficient choices in a given market.

In residential markets, program designs like Home Performance with ENERGY STAR pursue bundles of measures saving up to 40 percent of heating and cooling costs, and costing $\$ 5,000$ to $\$ 10,000$ or more (for a typical single-family home, savings could exceed $\$ 300$ per year). In commercial markets, one finds comprehensive approaches including performance benchmarking, ${ }^{5}$ retro-commissioning, ${ }^{6}$ and customized retrofits, used as part of a range of financial incentives, technical services, and bundled services/incentives.

4. Design the incentives. Well-designed incentives address the key market barriers in the target market. Financial incentives are designed to be just high enough to gain the desired level of program participation. In some cases, financial incentives can be bundled with financing, information, or technical services to reach program participation and energy savings goals at lower total program cost than using financial incentives alone. For example, a new home construction program could be designed to offer homebuyers cash incentives for buying high-efficiency homes. However, this incentive 
design may not address the key market barrier, which is homebuilders' limited motivation to design and build such homes, and could thus lead to very low participation levels. The most successful programs focus more resources on builders than buyers; and many have found that giving builders the technical assistance needed to design and build highefficiency homes can be at least as effective as cash incentives.

For more straightforward equipment rebates where the incentive design process mainly involves determining how much of the cost of a product to offer the customer, the process can be fairly simple, as illustrated in the following example steps:

- Product A, a high-efficiency model, costs $\$ 500$.

- Product B, a standard model, costs $\$ 400$.

- The incremental cost of Product $A$ is $\$ 100$. This amount has been determined to be cost-effective.

- Market research has determined that reducing the incremental cost of Product A to $\$ 50$ will induce most customers in that market to purchase the product

- $\quad$ The program designer sets the incentive level at $\$ 50$.

This incentive design process should not be an abstract analytical effort. Engaging customers and trade allies in program design will provide a lot of the basic information on market barriers, incentive types and levels, and other services that may be needed to make the program work. Incentives designed using input from customers and trade allies are far more likely to be effective than those designed in abstract, and continuing regular feedback and market observation allows program designers and operators to update the programs as market conditions and program success change over time. Feedback should be part of sound program management as an internal process; it may also take the shape of third-party evaluation of processes. For internal purposes, feedback can be reviewed monthly, quarterly, or annually; more formal process evaluations typically occur at least one year after program launch.

\section{Incentive Design Options}

This section provides examples of how different types of incentives are applied, the extent to which they support key impacts that efficiency programs seek to achieve, and some of their principal advantages and disadvantages:

- Direct incentives. These provide direct payments, tax incentives, or other subsidies to consumers for purchasing and implementing specified efficient products and practices. Cash payments typically take the form of rebate checks returned to customers following approval of a submitted rebate application. Utility bill credits show up as deductions from subsequent customer utility bills. Subsidized financing might include reduced interest rates, extended loan terms, or relaxed underwriting criteria. Advantages of financial incentives can include simplicity, ease of administration, and direct economic benefit to participating customers (although care must be taken to make them user-friendly to customers). Disadvantages include potentially high cost to program sponsors if market conditions require high incentive levels, the potential for failing to address key market barriers, limited ability to transform markets in the longer term (i.e., markets may stop buying efficient products when direct incentives stop), or the opposite-the market 
transforming more quickly than anticipated, leading to high free-ridership (the program paying incentives for things that would have happened on their own).

- Upstream/midstream incentives. These provide incentives not to customers, but to partners in the market supply chain: "upstream" incentives reach relatively far up the supply chain, typically to manufacturers; "midstream" incentives are targeted closer to the customer end of the market, typically at retailers or installation contractors. For example, upstream incentives can involve payments to manufacturers for making efficient products, or paying building designers to incorporate high-efficiency designs. Midstream incentives can include payments to retailers for stocking, promoting, or selling specified efficient products, or payments to contractors for installing heating and cooling equipment using specified quality procedures. Upstream and midstream incentives offer the advantage that incentive amounts can sometimes be lower, as market partners may need less "convincing" to make or sell efficient technologies. They can also help condition markets for longer-term changes in product specifications, stocking patterns, and so on. Upstream incentives alone, however, may not educate or engage customers enough to change wider customer perceptions, purchasing patterns, or behavior.

- Information services. Informational services that encourage customer energy efficiency investment and energy-saving behavior change can include home or facility energy assessments, technology-specific information materials, and product labeling and branding programs like ENERGY STAR. Providing enhanced utility billing data and related information can also support customer awareness and action. Training can range from teaching contractors to sell the benefits of efficient products to engaging architecture/engineering firms to evaluate and recommend efficient building designs. Advantages of information services include low cost, broad market reach, and addressing fundamental barriers. Disadvantages include limitations in addressing other key barriers, limitations in affecting specific market participants and transactions, and lack of long-term impacts without continued funding.

- Technical services. Technical services go beyond information services: they provide analysis and professional support for specific projects, while information services tend to address broad markets and customer types. In some markets, professional help in developing projects to the point of installation, and even in providing construction management services, is extremely valuable. This is especially true in corporate and institutional markets, where capital and financing are available and an economically attractive investment is likely to be implemented. Technical service incentive approaches have the advantage of relatively low cost compared to the total investment, as well as being targeted to specific markets and customers. If coupled with broader training and market development efforts, they can also transform wider markets by changing professional practices. Disadvantages include potentially limited total market impact, the limited availability of specialized expertise for such efforts, and the limited market and project types for which this approach is applicable.

- Bundled incentives and services. Mixing a set of monetary incentives with other services to achieve both greater program impact and more lasting market transformation effects is a strong trend in today's leading energy efficiency programs. As program sponsors gain experience through customer and trade ally interaction and through program evaluations, they often find that monetary incentives shrink as a fraction of total program costs, while other services evolve to extend program impacts. See the text box below for examples of such multi-faceted programs. The principal advantage of the 
bundled approach is its effectiveness in reaching specific markets; it can also improve total program impact and program cost-effectiveness. Disadvantages include complexity, potential high costs, and limited transferability to other markets (for example, a complex technical assistance service aimed at larger commercial/industrial customers might not be applicable or cost-effective for small commercial customer markets).

Table 3 summarizes the effectiveness of the five main incentive types in attaining key impacts. The high/medium/low estimates in each cell are indicative only; much depends on the details and the context in which the incentive is applied in a specific market and program design. These judgments are necessarily subjective, but because they are based on program experience across the United States they provide reasonable guidance for program designers and policymakers.

Table 3. Comparative Impacts of Incentive Types

\begin{tabular}{|l|c|c|c|c|c|}
\hline \multicolumn{1}{|c|}{ Key Impacts } & $\begin{array}{c}\text { Direct } \\
\text { Financial } \\
\text { Incentives }\end{array}$ & $\begin{array}{c}\text { Upstream/ } \\
\text { Midstream } \\
\text { Incentives }\end{array}$ & $\begin{array}{c}\text { Information } \\
\text { Services }\end{array}$ & $\begin{array}{c}\text { Technical } \\
\text { Services }\end{array}$ & $\begin{array}{c}\text { Bundled } \\
\text { Incentives/ } \\
\text { Services }\end{array}$ \\
\hline $\begin{array}{l}\text { Impact on Capital } \\
\text { Investment }\end{array}$ & $\mathrm{H}$ & $\mathrm{M}$ & $\mathrm{L}$ & $\mathrm{M}$ & $\mathrm{H}$ \\
\hline $\begin{array}{l}\text { Impact on Behavior } \\
\text { Change }\end{array}$ & $\mathrm{H}$ & $\mathrm{M}$ & $\mathrm{M}$ & $\mathrm{M}$ & $\mathrm{M}$ \\
\hline $\begin{array}{l}\text { Impact on Customer } \\
\text { Decisions }\end{array}$ & $\mathrm{L}$ & $\mathrm{H}$ & $\mathrm{M}$ & $\mathrm{L}$ & $\mathrm{H}$ \\
\hline $\begin{array}{l}\text { Impact on Third Party } \\
\text { Decisions }\end{array}$ & $\mathrm{H}$ & $\mathrm{H}$ & $\mathrm{L}$ & $\mathrm{M}$ & $\mathrm{H}$ \\
\hline Impact on Participation & $\mathrm{M}$ & $\mathrm{L}$ & $\mathrm{L}$ & $\mathrm{M}$ & $\mathrm{H}$ \\
\hline Impact on Energy Savings & $\mathrm{L}$ & $\mathrm{M}$ & $\mathrm{H}$ & $\mathrm{M}$ & $\mathrm{M}$ \\
\hline $\begin{array}{l}\text { Impact on Measurement } \\
\text { and Verification } \\
\text { Complexity/Cost }\end{array}$ & $\mathrm{L}$ & $\mathrm{M}$ & $\mathrm{L}$ & $\mathrm{M}$ & $\mathrm{M}$ \\
\hline $\begin{array}{l}\text { Impact on Regulatory } \\
\text { Approval }\end{array}$ &
\end{tabular}

$\mathrm{H}=$ highly likely to be effective for the incentive and its role;

$M=$ moderately likely to be effective; $L=$ low likelihood of being effective

Elaborating on Table 3, incentives' impacts may vary in the following areas:

- Capital investment. Getting customers to invest in efficiency projects typically takes either direct incentives or a bundle of incentives and services. Information alone does not tend to have a strong impact, but upstream incentives or technical services can have a moderate impact in some markets.

- Behavior/practice change. Encouraging customers to change the way they use appliances or operate buildings is best impacted by information services. Financial incentives may not be as effective and may be unnecessarily costly for this purpose. Technical assistance and bundled offerings can be effective. 
- Customer decisions vs. third-party decisions. Customers tend to respond best to direct financial incentives, though upstream/midstream incentives and information and technical services can have moderate impacts. Third parties in the supply chain are best impacted by upstream incentives.

- Participation. Getting customers to sign up for programs is typically achieved most effectively by some form of financial incentive, with lesser impacts from information or technical assistance alone.

- Magnitude of energy savings. The best way to realize high energy savings per customer is to use bundled offerings with high financial incentives and significant technical services, though direct incentives or technical services can have a moderate impact, depending on the market.

- Measurement and verification complexity/cost. Information programs tend to be lower-cost than financial incentive programs, but they present challenges that may raise the cost of monitoring, verification, and other evaluation needs. Many direct rebates can be relatively simple for these purposes. 


\section{Emerging Incentive/Service Approaches for Whole-Building, Deep Savings}

The National Action Plan for Energy Efficiency Vision for 2025, in seeking to implement all costeffective energy efficiency, encompasses an approach that not only mines efficiency in all major markets, but also seeks deeper levels of savings per customer. The early years of an efficiency program effort are designed to secure the most cost-effective and rapidly attainable efficiency savings, often through direct incentives offered on a mass market basis. This approach can generate substantial impacts and can reach several markets, but it tends to realize limited savings on a per-customer basis.

For example, in residential markets, early program designs may target lighting and appliances, as many of these measures are very cost-effective, can be deployed broadly across mass markets, and can drive large total energy impacts. But the majority of the cost-effective potential in the residential sector may lie in more expensive, comprehensive program approaches that target heating, cooling, and hot water end uses and thermal envelope improvements. Likewise, in nonresidential markets, lighting retrofits can be very cost-effective and achieve large savings, but do not directly tap the savings to be found in heating, ventilation, and air conditioning (HVAC) systems.

Experienced program sponsors today are deploying these more-comprehensive program models, often while keeping up many of their proven, successful mass market and targeted incentive programs. Comprehensive programs in a well-designed portfolio can complement rather than supplant simpler and mass market approaches. Examples of innovative program models in this category include:

- Home Performance With ENERGY STAR: http://www.energystar.gov/homeperformance

- Xcel Energy Commercial Real Estate Efficiency program: http://www.xcelenergy.com/Minnesota/Business/Programs Resources/ConservationRebat es Incentives Business/Pages/Commercial Real Estate.aspx

- New Jersey Clean Energy Pay for Performance: http://www.njcleanenergy.com/commercial-industrial/programs/pay-performance

- Energy Trust of Oregon: http://energytrust.org/business/incentives/commercial-buildings/newbuilding/custom/custom-track-incentives

- Building Performance With ENERGY STAR (an NSTAR performance-based incentive pilot program): http://www.nstaronline.com/business/energy efficiency/electric programs/benchmark.asp 


\section{Emerging Data Center Energy Efficiency Programs}

Within both new construction and retrofit program portfolios, program administrators are exploring new program designs to incent greater energy efficiency in data centers. Examples of emerging data center energy efficiency programs include:

- Pacific Gas and Electric:

http://www.pge.com/includes/docs/pdfs/mybusiness/energysavingsrebates/incentivesbyi ndustry/hightech/data center baseline2009-10-01.pdf

- Energy Trust of Oregon/New Data Center incentive:

http://energytrust.org/TA/insider/0908/ExistingBuildings.html

- Xcel/Colorado:

http://www.xcelenergy.com/Colorado/Business/Programs Resources/ConservationReba tes Incentives Business/Pages/DataCenterEfficiency.aspx

- Austin Energy:

http://www.austinenergy.com/Energy\%20Efficiency/Programs/Rebates/Commercial/Com mercial\%20Energy/dataCenter.htm

\section{Program Experience: Summary of Incentives Offered in Best-Practice Programs}

This section summarizes a mix of quantitative and qualitative experience with incentives as they are offered through energy efficiency programs in the field. Table 4 is built on the same basic structure as those above; however, it does not report information on financing or information services, as available data were either insufficient or unsuitable for this summary format. 
Table 4. Summary of Incentives Offered in Current Programs

\begin{tabular}{|c|c|c|c|c|}
\hline \multirow{2}{*}{$\begin{array}{l}\text { Customer } \\
\text { Types/Markets }\end{array}$} & \multicolumn{4}{|c|}{ Incentive Types } \\
\hline & Direct Incentives & Indirect Incentives & Technical Services & $\begin{array}{l}\text { Bundled } \\
\text { Incentives/Services }\end{array}$ \\
\hline \multicolumn{5}{|l|}{ Residential } \\
\hline $\begin{array}{l}\text { New } \\
\text { construction }\end{array}$ & Direct incentives to consumers are rare ${ }^{a}$ & $\begin{array}{l}\text { Builder incentives } \\
\text { typically range from } \\
\$ 400 \text { to } \$ 2,000 / \text { home } \\
\text { Incentives for ENERGY } \\
\text { STAR Advanced } \\
\text { Lighting Package range } \\
\text { from } \$ 100 \text { to } \$ 525 / \text { home }\end{array}$ & $\begin{array}{l}\text { Technical services for } \\
\text { builders and contractors } \\
\text { include: } \\
\text { - } \quad \text { Design assistance } \\
\text { - } \quad \text { Contractor training } \\
\text { - } \quad \text { Sales training } \\
\text { - } \quad \begin{array}{l}\text { Free/shared-cost } \\
\text { energy rating services }\end{array}\end{array}$ & $\begin{array}{l}\text { Programs may also offer: } \\
\begin{array}{l}\text { - } \quad \text { Builder financing } \\
\text { - Cooperative marketing } \\
\text { and advertising } \\
\text { - Bonuses for installing } \\
\text { high-efficiency } \\
\text { appliances, lighting, or } \\
\text { HVAC equipment }\end{array}\end{array}$ \\
\hline $\begin{array}{l}\text { Lighting/low- } \\
\text { cost retrofit }\end{array}$ & $\begin{array}{l}\text { Typical ranges: } \\
\begin{array}{l}\text { - } \\
\text { - } \quad \text { CFixtures: } \$ 10-\$ 20^{c} \\
\text { - } \quad \text { Ceiling fans: } \$ 15-\$ 20^{\mathrm{e}}\end{array}\end{array}$ & $\begin{array}{l}\text { Manufacturer and/or } \\
\text { retailer buy-downs on } \\
\text { specified products; } \\
\text { some sponsors use a } \\
\text { request for proposals } \\
\text { process }^{f}\end{array}$ & $\begin{array}{l}\text { Technical support can } \\
\text { include: } \\
\text { - } \quad \text { Education and } \\
\text { outreach efforts } \\
\text { - Developing standards } \\
\text { of practice for } \\
\text { participating } \\
\text { contractors } \\
\text { Enhancing displays } \\
\text { and increasing } \\
\text { qualified product } \\
\text { inventory }\end{array}$ & $\begin{array}{l}\text { Programs may also offer } \\
\text { direct install programs } \\
\text { focused on no- and low- } \\
\text { cost upgrades, such as: } \\
\text { - } \quad \text { CFLs } \\
\text { - } \quad \text { Low-flow shower heads } \\
\text { - Faucet aerators } \\
\text { - Programmable } \\
\text { thermostats } \\
\text { Cooperative marketing } \\
\text { and advertising, special } \\
\text { promotions and events }\end{array}$ \\
\hline
\end{tabular}




\begin{tabular}{|c|c|c|c|c|}
\hline \multirow{2}{*}{$\begin{array}{l}\text { Customer } \\
\text { Types/Markets }\end{array}$} & \multicolumn{4}{|c|}{ Incentive Types } \\
\hline & Direct Incentives & Indirect Incentives & Technical Services & $\begin{array}{l}\text { Bundled } \\
\text { Incentives/Services }\end{array}$ \\
\hline $\begin{array}{l}\text { Higher-cost } \\
\text { retrofit }\end{array}$ & $\begin{array}{l}\text { Typical ranges: } \\
\text { - } \quad \text { Building envelope (windows, } \\
\text { insulation): } \$ 1-\$ 10 \text { (per square } \\
\text { foot) } \\
\text { - Equipment system upgrades, e.g., } \\
\$ 300 \text { rebate for duct sealing } \\
\text { - } \begin{array}{l}\text { Project subsidy, e.g., } 70 \% \text { of } \\
\text { comprehensive HVAC/envelope } \\
\text { project cost }^{\mathrm{k}}\end{array}\end{array}$ & $\begin{array}{l}\text { Remodeler incentives } \\
\text { for installing the } \\
\text { ENERGY STAR } \\
\text { Advanced Lighting } \\
\text { Package for major } \\
\text { renovation: } \\
\text { - } \$ 100 \text { to } \$ 525 / \text { home }\end{array}$ & $\begin{array}{l}\text { Technical services can } \\
\text { include: } \\
\text { - } \quad \text { Contractor/trade ally } \\
\text { education/outreach } \\
\text { - Developing standards } \\
\text { for participating } \\
\text { contractors }^{\mathrm{m}} \\
\text { - Diagnostic energy } \\
\text { audit } \\
\text { - Conducting field visits } \\
\text { and training }\end{array}$ & $\begin{array}{l}\text { Programs may also offer: } \\
\text { - Low-interest financing } \\
\text { - Point of sale financing }\end{array}$ \\
\hline $\begin{array}{l}\text { Equipment } \\
\text { replacement }\end{array}$ & $\begin{array}{l}\text { Typical ranges: } \\
\begin{array}{l}\text { - } \text { Clothes washers: } \$ 50-\$ 75 \\
\text { - } \text { Dishwashers: } \$ 25-\$ 50 \\
\text { - } \text { Refrigerators: } \$ 25-\$ 50 \\
\text { - } \text { Room air conditioning: } \$ 25-\$ 35 \\
\text { - HVAC equipment: } \$ 100-\$ 1,200^{p}\end{array}\end{array}$ & & $\begin{array}{l}\text { Technical support can } \\
\text { include: } \\
\text { - Contractor training on } \\
\text { quality installation, } \\
\text { sizing, etc. } \\
\text { - Developing standards } \\
\text { for participating } \\
\text { contractors }{ }^{q} \\
\text { - Field visits and training } \\
\text { r }\end{array}$ & \\
\hline
\end{tabular}




\begin{tabular}{|c|c|c|c|c|}
\hline \multirow{2}{*}{$\begin{array}{l}\text { Customer } \\
\text { Types/Markets }\end{array}$} & \multicolumn{4}{|c|}{ Incentive Types } \\
\hline & Direct Incentives & Indirect Incentives & Technical Services & $\begin{array}{l}\text { Bundled } \\
\text { Incentives/Services }\end{array}$ \\
\hline \multicolumn{5}{|c|}{ Small Commercial } \\
\hline $\begin{array}{l}\text { New } \\
\text { construction }\end{array}$ & \multicolumn{4}{|c|}{ Small commercial new construction programs are rare } \\
\hline $\begin{array}{l}\text { Lighting/low- } \\
\text { cost retrofit }\end{array}$ & $\begin{array}{l}\text { Typical ranges: } \\
\text { Fluorescent fixtures } \\
\text { - } \$ 1-\$ 200 \text { per fixture } \\
\text { - } \quad 30 \%-50 \% \text { of project cost } \\
\text { Sensors } \\
\text { - } \quad \$ 10-\$ 75 \text {, depending on sensor type } \\
\text { LED linear fixtures } \\
\text { - } \$ 2-\$ 6 \\
\text { Exit signs } \\
\text { - } \quad \$ 10-\$ 75 \text { (typically for LED signs) }^{\mathrm{s}}\end{array}$ & $\begin{array}{l}\text { Program sponsors may } \\
\text { offer: } \\
\begin{array}{l}\text { Additional incentives } \\
\text { to lighting } \\
\text { contractors } \\
\text { Manufacturer buy- } \\
\text { downs through a } \\
\text { request for } \\
\text { proposals process }\end{array}\end{array}$ & 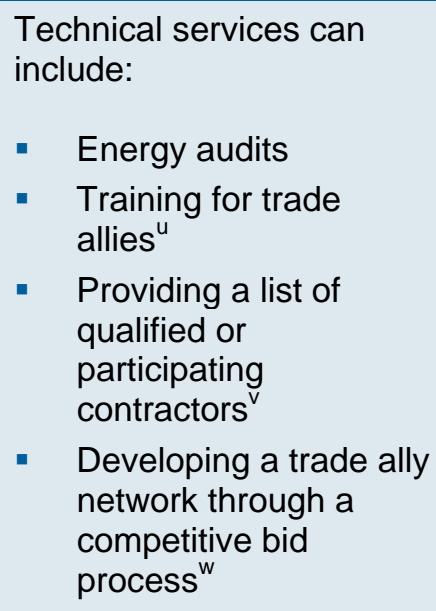 & 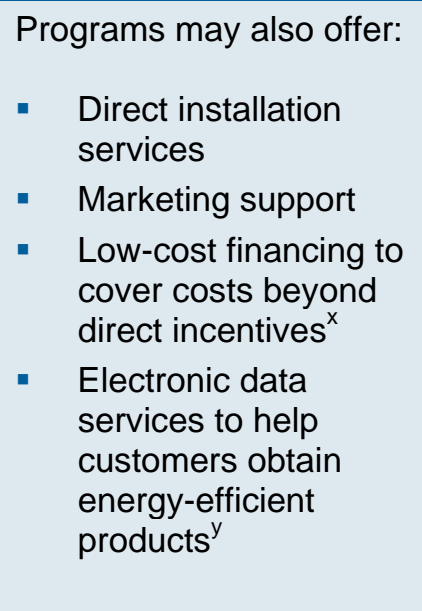 \\
\hline $\begin{array}{l}\text { Higher-cost } \\
\text { retrofit }\end{array}$ & $\begin{array}{l}\text { Direct incentives include: } \\
\text { Covering a percentage of installed } \\
\text { project costs (e.g., } 50 \% \text { of installed } \\
\text { costs) }\end{array}$ & & $\begin{array}{l}\text { Technical support can } \\
\text { include: } \\
\text { - Site energy } \\
\text { assessments at low or } \\
\text { no cost }^{\mathrm{aa}} \\
\text { Trade ally training and } \\
\text { technical support } \\
\text { Developing qualified } \\
\text { trade ally networks }^{\mathrm{bb}}\end{array}$ & $\begin{array}{l}\text { Programs may also offer: } \\
\text { - Project development } \\
\text { services } \\
\text { - Low-cost financing for } \\
\text { project costs beyond } \\
\text { direct incentive } \\
\text { paymentsc }\end{array}$ \\
\hline
\end{tabular}




\begin{tabular}{|c|c|c|c|c|}
\hline \multirow{2}{*}{$\begin{array}{l}\text { Customer } \\
\text { Types/Markets }\end{array}$} & \multicolumn{4}{|c|}{ Incentive Types } \\
\hline & Direct Incentives & Indirect Incentives & Technical Services & $\begin{array}{l}\text { Bundled } \\
\text { Incentives/Services }\end{array}$ \\
\hline $\begin{array}{l}\text { Equipment } \\
\text { replacement }\end{array}$ & $\begin{array}{l}\text { Typical ranges: } \\
\text { - Commercial food service } \\
\text { equipment: } \$ 200-\$ 600 \\
\text { - Project incentives (percentage of } \\
\text { project costs) }\end{array}$ & & $\begin{array}{l}\text { Technical services can } \\
\text { include: } \\
\text { - Recruiting and training } \\
\text { trade allies } \\
\text { Developing qualified } \\
\text { trade ally lists and } \\
\text { networks }\end{array}$ & $\begin{array}{l}\text { Programs may also offer: } \\
\text { - Low-cost financing for } \\
\text { project costs } \\
\text { Direct incentive } \\
\text { payments }\end{array}$ \\
\hline \multicolumn{5}{|c|}{ Large Commercial/Industrial } \\
\hline $\begin{array}{l}\text { New } \\
\text { construction }\end{array}$ & $\begin{array}{l}\text { Direct incentives vary from prescriptive } \\
\text { rebates per measure, similar to those } \\
\text { offered for retrofit or replacement, to } \\
\text { performance-based incentives based } \\
\text { on energy/demand reductions }{ }^{\text {dd }}\end{array}$ & $\begin{array}{l}\text { Some programs offer } \\
\text { incentives to the design } \\
\text { team to encourage } \\
\text { comprehensive, whole } \\
\text { building upgrades } \\
\text { starting early in the } \\
\text { design process }^{\text {ee }}\end{array}$ & $\begin{array}{l}\text { Technical support can } \\
\text { include: } \\
\text { - } \quad \text { Design assistance for } \\
\text { specific projects } \\
\text { - Helping customers and } \\
\text { designers set } \\
\text { performance targets, } \\
\text { using tools such as } \\
\text { ENERGY STAR Target } \\
\text { Finder (\$2,000- } \\
\$ 30,000 \text { per project) })^{\mathrm{ff}}\end{array}$ & $\begin{array}{l}\text { Over time, some programs } \\
\text { evolve to a comprehensive } \\
\text { set of education, design } \\
\text { assistance, market } \\
\text { transformation, and direct } \\
\text { incentives }^{\text {ff }}\end{array}$ \\
\hline $\begin{array}{l}\text { Lighting/low- } \\
\text { cost retrofit }\end{array}$ & $\begin{array}{l}\text { Typical ranges: } \\
\text { Lighting systems } \\
\quad 30 \%-75 \% \text { of project cost } \\
\text { - } \$ 0.03-\$ 0.75 / \text { kilowatt-hour saved }{ }^{g g} \\
\text { Sensors } \\
\quad \$ 10-\$ 75 \text {, depending on sensor type }\end{array}$ & $\begin{array}{l}\text { See Small Commercial } \\
\text { Section }\end{array}$ & $\begin{array}{l}\text { See Small Commercial } \\
\text { Section }\end{array}$ & $\begin{array}{l}\text { See Small Commercial } \\
\text { Section }\end{array}$ \\
\hline
\end{tabular}




\begin{tabular}{|c|c|c|c|c|}
\hline \multirow{2}{*}{$\begin{array}{l}\text { Customer } \\
\text { Types/Markets }\end{array}$} & \multicolumn{4}{|c|}{ Incentive Types } \\
\hline & Direct Incentives & Indirect Incentives & Technical Services & $\begin{array}{l}\text { Bundled } \\
\text { Incentives/Services }\end{array}$ \\
\hline $\begin{array}{l}\text { Higher-cost } \\
\text { retrofit }\end{array}$ & 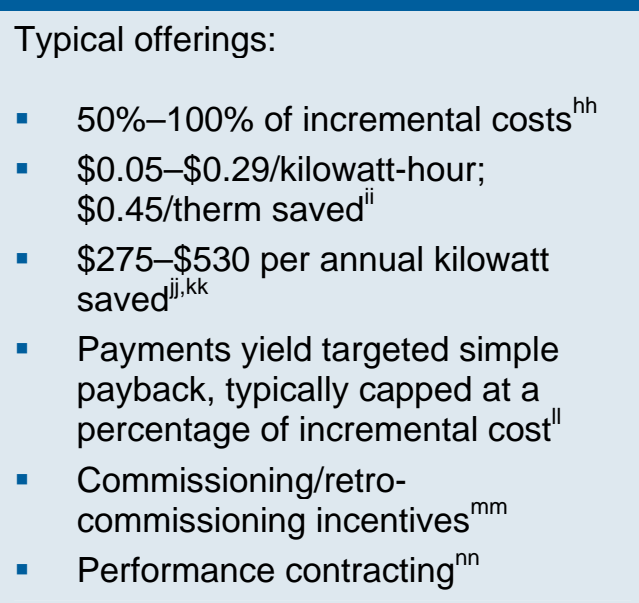 & & $\begin{array}{l}\text { Technical support can } \\
\text { include: } \\
\text { Trade ally and } \\
\text { customer staff training } \\
\text { and technical support } \\
\text { Free/shared cost for } \\
\text { technical services } \\
\text { topp }\end{array}$ & $\begin{array}{l}\text { Programs may also offer: } \\
\text { - Financing }{ }^{\mathrm{qq}} \\
\text { - Onsite energy } \\
\text { engineers for extended } \\
\text { periods }\end{array}$ \\
\hline $\begin{array}{l}\text { Equipment } \\
\text { replacement }\end{array}$ & $\begin{array}{l}\text { Direct incentives can be prescriptive as } \\
\text { outlined above, but for larger customers } \\
\text { they tend to be more customized, as } \\
\text { equipment is used in more complex and } \\
\text { specific applications. Such incentives } \\
\text { tend to pay a portion of the incremental } \\
\text { cost for efficient equipment or systems }\end{array}$ & $\begin{array}{l}\text { Upstream incentives } \\
\text { targeted to equipment } \\
\text { suppliers may overcome } \\
\text { market barriers more } \\
\text { easily than consumer- } \\
\text { oriented incentives }^{\text {ss }}\end{array}$ & $\begin{array}{l}\text { Technical services can } \\
\text { include: } \\
\text { Training efforts to } \\
\text { expose consumers and } \\
\text { suppliers to the } \\
\text { benefits of energy- } \\
\text { efficient equipment or } \\
\text { practices }^{\text {tt }}\end{array}$ & \\
\hline \multicolumn{5}{|c|}{ See table notes on next page. } \\
\hline
\end{tabular}




\section{Table notes}

a Purchasers of ENERGY STAR-qualified homes receive a lower electricity rate (approximately 5 percent lower) from Jackson Electric Membership Corporation (see http://www.jacksonemc.com).

Source: Alliant Energy (2009), MidAmerican Energy (2009).

c Source: DOE and EPA (2010).

d Source: DOE and EPA (2010).

e Source: DOE and EPA (2010).

f Source: York et al. (2008).

g California investor-owned utilities and Efficiency Vermont. Source: National Action Plan for Energy Efficiency (2006), Chapter 6.

h California. Source: Quantum Consulting (2004e), p. 35.

i Source: DOE and EPA (2010).

j Sacramento Municipal Utility District (California). Source: Quantum Consulting (2004e), p. 33, Exhibit R4-6.

k Tacoma Residential Weatherization Program (California). Source: Quantum Consulting (2004e), p. 33, Exhibit R4-6.

I California investor-owned utilities and Efficiency Vermont. Source: National Action Plan for Energy Efficiency (2006), Chapter 6.

m California. Source: Quantum Consulting (2004e), p. 35.

n Source: York et al. (2008).

- California. Source: Quantum Consulting (2004e), p. 29, Exhibit R4-5.

p Source: DOE and EPA (2010).

q California. Source: Quantum Consulting (2004e), p. 35.

r Source: York et al. (2008).

s Source: North Carolina Solar Center (2009).

t Source: York et al. (2008).

u Source: Quantum Consulting (2004d).

$v$ Seattle City Light. Source: National Action Plan for Energy Efficiency (2006), Chapter 6.

w National Grid (Massachusetts and Rhode Island). Source: York et al. (2008).

$x$ Small Business Energy Advantage (Connecticut). Source: York et al. (2008).

y Source: Quantum Consulting (2004a).

z Small Business Energy Advantage (Connecticut). Source: York et al. (2008).

aa Small Business Energy Advantage (Connecticut). Source: York et al. (2008).

bb National Grid (Massachusetts and Rhode Island). Source: York et al. (2008).

cc Small Business Energy Advantage (Connecticut). Source: York et al. (2008).

dd Source: DOE and EPA (2010).

ee National Grid (Massachusetts and Rhode Island) and California statewide energy efficiency program. Source: York et al. (2008).

If National Grid (Massachusetts and Rhode Island). Source: York et al. (2008). 
National Grid (Massachusetts and Rhode Island). Source: York et al. (2008).

hh

For example, ComEd: http://www.comed.com.

ii For example, ComEd: http://www.comed.com.

ij Energy Trust of Oregon: http://energytrust.org.

kk Source: National Action Plan for Energy Efficiency (2006), Chapter 6.

" Source: North Carolina Solar Center (2009).

mm California. Source: Quantum Consulting (2004c), pp. 46-47, Exhibit NR5-6.

nn California Standard Performance Contracts and NYSERDA Commercial and Industrial Performance Program from California. Source: Quantum Consulting (2004c), pp. 46-47, Exhibit NR5-6.

oo Xcel (Colorado) and Sacramento Municipal Utility District (California). Source: Quantum Consulting (2004c), pp. 46-47, Exhibit NR5-6.

pp Rocky Mountain Power (Washington and Nevada). Source: York et al. (2008).

q9 NGrid and United Illuminating Company from California. Source: Quantum Consulting (2004c), pp. 4647, Exhibit NR5-6.

rr Source: Amann and Mendelsohn (2005).

ss NYSERDA. Source: National Action Plan for Energy Efficiency (2006), Chapter 6.

tt California. Source: Quantum Consulting (2004c), pp. 46-47, Exhibit NR5-6.

uи Rocky Mountain Power (Washington and Nevada). Source: York et al. (2008).

wv Wisconsin Power and Light Shared Savings (Wisconsin). Source: Quantum Consulting (2004c), pp. 46-47, Exhibit NR5-6.

ww California. Source: Quantum Consulting (2004b), p. 17.

xx Pacific Gas and Electric Company. Source: York et al. (2008).

yy California. Source: Quantum Consulting (2004b), p. 17. 


\section{Considerations in Reviewing, Designing, and Implementing Program Incentives}

Incentive designs and levels in specific programs and portfolios can vary based on a range of local considerations. These include:

- Climate. Some measures may not be appropriate in some climate zones, and incentives for such measures may not be justified. For example, in the warmest Sun Belt climates, incentives for high-efficiency heating systems may be inappropriate while efficient cooling systems may be very cost-effective. The appropriate level of an incentive, however, does not necessarily vary in the same way. If a cooling measure is very costeffective in a hot climate, customers and trade allies may need relatively small incentives, whereas in milder climates, higher incentives may be needed to produce comparable paybacks.

- Customer mix. The types and sizes of customer facilities, and their ownership patterns, can affect the balance of incentive offerings in a portfolio. For example, residential lowincome customers have unique needs and may be offered efficiency services from other funding sources. As another example, a higher fraction of customers may occupy rental property in highly urbanized areas. This can call for a greater emphasis on incentives and program designs aimed at building owners distinct from tenant/occupants. If commercial customers are predominantly small businesses, a simple direct installation approach may work better than a complex comprehensive incentive system. In practice, most areas contain enough of the typical customer types to justify a robust range of program incentives across the portfolio.

- Building stock. Age, construction type, and other characteristics of the building stock may influence incentive and program focus. Where the housing stock is older, there may be a greater need for comprehensive incentives that seek to bundle envelope improvements with HVAC and other measures. Where housing stock is newer, there may be more focus on prescriptive incentives for appliances and other "plug-load" measures.

- Industrial base. If there are a few large, corporate industrial customers in the service area, program incentives may be quite customized, even customer-driven, as customers may be technically sophisticated. Where industrial customers are more small businessbased, a more basic set of incentives and technical services may be appropriate

- Existing programs. Many states and localities have existing energy efficiency programs to draw upon, and so any new efforts should be designed to complement such efforts. Federal incentives may also be available. For example, the Energy Policy Act of 2005 created a range of home and business tax incentives, some of which were expanded in the American Recovery and Reinvestment Act (ARRA) of 2009 (http://www.energystar.gov/index.cfm?c=tax credits.tx index). Program designs and portfolios should seek to leverage these resources as available. For example, the ARRA substantially increased residential tax credits for envelope, HVAC, and hot water measures through 2010. These can be used as leverage by tuning program incentives and services to make best use of these resources to drive participation. Because tax incentives are typically quite time-limited, they can help accelerate participation during their eligibility period. ${ }^{7}$ 
Program incentives are also subject to forces in the regulatory environment. Some states have climate policies that make energy efficiency a centerpiece, driving both mandates and funding for energy efficiency. Many states have policies in place to set energy savings targets for utilitysector efficiency programs (energy efficiency resource standards), to provide public funding for efficiency program (public benefits funds), or to require utilities to include efficiency as a resource in integrated resource plans. When resource targets are set, and certain savings levels must be achieved, the need to attain those goals can drive incentive levels and program portfolio decisions. Setting incentive levels somewhat higher, within the range set by costeffectiveness tests, can drive participation and program savings higher in a given time period. Other program features, such as technical services, training trade allies, and offering upstream incentives, can exert market transformation effects over time, but may not show as significant an impact in the near term.

\section{Key Questions to Ask Regarding Customer Incentives in Program Design}

When reviewing program plans, the following questions can help illuminate the key issues that can make a difference between successful and unsuccessful offerings:

- Are the incentives and other program strategies based on a clear, logical program theory that identifies barriers in the target market and designs incentives and other strategies to reduce those barriers?

- Is the program theory based on, and validated by, a detailed market assessment that examines key market actors and decision-making processes?

- Is the program part of a wider portfolio of energy efficiency programs, and if so does it provide appropriate incentives within the portfolio's context? Are incentive levels and other services appropriate for the developmental cycle of the program and the wider portfolio?

- Does the program design consider and seek to leverage other incentive options, such as federal, state, or local tax incentives, or other programs or services?

- Are incentives and other program strategies proven to be effective elsewhere? Has the program designer provided solid evidence of its success in other markets?

- Are incentive and other program strategies appropriate to the climate, customer mix, and local market characteristics?

- Did program designers consult customers and trade allies in designing incentives and other program features?

- Are customer incentives part of a complete program plan, including infrastructure development, marketing, and program implementation and evaluation?

- What may be the unintended consequences of providing the incentives? Can program strategies be designed to reduce any potential negative consequences?

- Is the proposed program or portfolio cost-effective applying the jurisdiction's applicable cost-effectiveness tests? 


\section{Notes}

1 For information on the full suite of policy and programmatic options to remove barriers to energy efficiency, see the Vision for 2025 and other Action Plan resources available at www.epa.gov/eeactionplan.

2 Program portfolios offer a suite of services that in combination reach all of the customer classes with efficiency services; in total, they provide cost-effective energy efficiency to the utility and society. See National Action Plan for Energy Efficiency (2006), Chapter 6.

3 Energy Trust of Oregon developed a Lost Opportunity Policy to address to what extent program designers and staff should emphasize avoiding lost opportunities in their efficiency programs. This policy is available at http://energytrust.org/library/policies/4.04.000-P.pdf

4 The term "structural barriers" used here is taken from McKinsey \& Company (2009). It is a subset of the broader term "market barriers" used in the National Action Plan report (National Action Plan for Energy Efficiency, 2006). Structural barriers, particularly the principal-agent problem, are explored in more depth in International Energy Agency (2007). The term "split-incentive" is an application of the more general "principal-agent" term from economic theory. Classical economics defines the principalagent problem as a situation in which one party acts as the "agent" on behalf of another party, the "principal," in a decision process. A typical example is home builders' role in specifying energy efficiency features of new homes, acting as "agents" on behalf of "principal" home buyers.

The term "financial barriers" used here is included within the broader terms "availability barriers" (used in the McKinsey report) and "customer barriers" (used in the National Action Plan report).

The term "informational barriers" used here corresponds to both "structural" and "behavioral" barriers as those terms are used in the McKinsey report, and to "market" and "customer" barriers in the National Action Plan report.

5 Performance benchmarking involves compiling a building's past energy use data, then comparing those data to benchmark values established through statistical analysis of comparable buildings or other metrics.

6 Retro-commissioning involves assessing a building's operating conditions, then making operational changes and equipment adjustments to improve operating performance.

7 Leveraging federal or other outside funding sources can create attribution issues; for example, if two entities (e.g., a utility and a state energy office) each contribute funds to a single program, an attribution method may be needed for each entity to appropriately claim and report program impacts and costs. 



\section{Appendix A: National Action Plan for Energy Efficiency Leadership Group}

\section{Co-Chairs \\ Marsha Smith \\ Commissioner, Idaho Public \\ Utilities Commission \\ Past President, National \\ Association of Regulatory Utility \\ Commissioners \\ James E. Rogers \\ Chairman, President, and \\ C.E.O. \\ Duke Energy \\ Leadership Group}

Barry Abramson

Senior Vice President

Servidyne Systems, LLC

Tracy Babbidge

Director, Air Planning

Connecticut Department of

Environmental Protection

Angela Beehler

Senior Director, Energy

Regulation/Legislation

Wal-Mart Stores, Inc.

Bruce Braine

Vice President, Strategic Policy

Analysis

American Electric Power

Jeff Burks

Director of Environmental

Sustainability

PNM Resources

Sandra Byrd

Vice President, Strategic Affairs

Arkansas Electric Cooperative

Corporation
Kateri Callahan

President

Alliance to Save Energy

Jorge Carrasco

Superintendent

Seattle City Light

Lonnie Carter

President and C.E.O.

Santee Cooper

Sheryl Carter

Co-Director, Energy Program

Natural Resources Defense

Council

Gary Connett

Director of Environmental

Stewardship and Member

Services

Great River Energy

Larry Downes

Chairman and C.E.O.

New Jersey Natural Gas (New

Jersey Resources Corporation)

Roger Duncan

General Manager

Austin Energy

Neal Elliott

Associate Director for Research

American Council for an

Energy-Efficient Economy

Angelo Esposito

Senior Vice President, Energy

Services and Technology

New York Power Authority

Jeanne Fox

President

New Jersey Board of Public

Utilities
Philip Giudice

Commissioner

Massachusetts Department of

Energy Resources

Dian Grueneich

Commissioner

California Public Utilities

Commission

Blair Hamilton

Policy Director

Vermont Energy Investment

Corporation

Stephen Harper

Global Director, Environment

and Energy Policy

Intel Corporation

Maureen Harris

Commissioner

New York State Public Service

Commission

Mary Healey

Consumer Counsel for the State

of Connecticut

Connecticut Consumer Counsel

Joe Hoagland

Vice President, Energy

Efficiency and Demand

Response

Tennessee Valley Authority

Val Jensen

Vice President, Marketing and

Environmental Programs

ComEd (Exelon Corporation)

Mary Kenkel

Consultant, Alliance One

Duke Energy 
Ruth Kiselewich

Director, Demand Side

Management Programs

Baltimore Gas and Electric

Company

Harris McDowell

Senator

Delaware General Assembly

Ed Melendreras

Vice President, Sales and

Marketing

Entergy Corporation

Janine Migden-Ostrander

Consumers' Counsel

Office of the Ohio Consumers'

Counsel

Michael Moehn

Vice President, Corporate

Planning

Ameren

Fred Moore

Director, Manufacturing and

Technology, Energy

The Dow Chemical Company

Richard Morgan

Commissioner

District of Columbia Public

Service Commission

Diane Munns

Vice President, Regulatory

Relations and Energy Efficiency

MidAmerican Energy Company

Clay Nesler

Vice President, Global Energy

and Sustainability

Johnson Controls, Inc.

Brock Nicholson

Deputy Director, Division of Air

Quality

North Carolina Department of

Environment and Natural

Resources
Jed Nosal

Chief, Office of Ratepayer

Advocacy

Massachusetts Office of

Attorney General Martha

Coakley

Pat Oshie

Commissioner

Washington Utilities and

Transportation Commission

Jim Parks

Manager, Energy Efficiency and

Customer R\&D

Sacramento Municipal Utility

District

John Perkins

Consumer Advocate

lowa Office of Consumer

Advocate

Doug Petitt

Vice President, Marketing and

Conservation

Vectren Corporation

Phyllis Reha

Commissioner

Minnesota Public Utilities

Commission

Roland Risser

Director, Customer Energy

Efficiency

Pacific Gas and Electric

Gene Rodrigues

Director, Energy Efficiency

Southern California Edison

Wayne Rosa

Energy and Maintenance

Manager

Food Lion, LLC

Art Rosenfeld

Commissioner

California Energy Commission

Ted Schultz

Vice President, Energy

Efficiency

Duke Energy
Larry Shirley

Director of the Green Economy

North Carolina Department of

Commerce

Paul Sotkiewicz

Senior Economist, Market

Services Division

PJM Interconnection

Jim Spiers

Senior Manager, Planning,

Rates, and Member Services

Tri-State Generation and

Transmission Association, Inc.

Susan Story

President and C.E.O.

Gulf Power Company (Southern

Company)

Tim Stout

Vice President, Energy

Efficiency

National Grid

Debra Sundin

Director, Energy Efficiency

Marketing

Xcel Energy

Paul Suskie

Chairman

Arkansas Public Service

Commission

Dub Taylor

Director

Texas State Energy

Conservation Office

David Van Holde

Energy Manager, Department of Natural Resources and Parks

King County, Washington

Brenna Walraven

Managing Director, National

Property Management

USAA Realty Company

J. Mack Wathen

Vice President, Regulatory

Affairs

Pepco Holdings, Inc. 
Mike Weedall

Vice President, Energy

Efficiency

Bonneville Power Administration

Michael Wehling

Strategic Planning and

Research

Puget Sound Energy

Henry Yoshimura

Manager, Demand Response

ISO New England, Inc.

\section{Dan Zaweski}

Assistant Vice President, Energy Efficiency and

Distributed Generation

Long Island Power Authority

\section{Observers}

Glen Andersen

Program Principal

National Conference of State

Legislatures

Rex Boynton

President

North American Technician

Excellence

James W. (Jay) Brew

Counsel

Steel Manufacturers Association

Susan Coakley

Executive Director

Northeast Energy Efficiency

Partnerships

Roger Cooper

Executive Vice President, Policy

and Planning

American Gas Association

Mark Crisson

President and C.E.O.

American Public Power

Association

Dan Delurey

Executive Director

Demand Response

Coordinating Committee
Reid Detchon

Executive Director

Energy Future Coalition

Ron Edelstein

Director, Regulatory and

Government Relations

Gas Technology Institute

Claire Fulenwider

Executive Director

Northwest Energy Efficiency

Alliance

Sue Gander

Director, Environment, Energy, and Natural Resources Division National Governors

Association-Center for Best

Practices

Jeff Genzer

General Counsel

National Association of State

Energy Officials

Donald Gilligan

President

National Association of Energy

Service Companies

Chuck Gray

Executive Director

National Association of

Regulatory Utility

Commissioners

Katherine Hamilton

President

GridWise Alliance

William Hederman

Member, IEEE-USA Energy

Policy Committee

Institute of Electrical and

Electronics Engineers

Marc Hoffman

Executive Director

Consortium for Energy

Efficiency
John Holt

Senior Manager, Generation

and Fuel

National Rural Electric

Cooperative Association

Eric Hsieh

Manager, Government

Relations

National Electrical

Manufacturers Association

Lisa Jacobson

Executive Director

Business Council for

Sustainable Energy

Wendy Jaehn

Executive Director

Midwest Energy Efficiency

Alliance

Meg Matt

President and C.E.O.

Association of Energy Services

Professionals

Joseph Mattingly

Vice President, Secretary and

General Counsel

Gas Appliance Manufacturers

Association

Kate Offringa

President and C.E.O.

North American Insulation

Manufacturers Association

Ellen Petrill

Director, Public/Private

Partnerships

Electric Power Research

Institute

Steven Schiller

Board Director

Efficiency Valuation

Organization

Jerry Schwartz

Senior Director, Energy and

Environmental Policy

American Forest and Paper

Association 
Andrew Spahn

Executive Director

National Council on Electricity

Policy

Ben Taube

Executive Director

Southeast Energy Efficiency

Alliance

Rick Tempchin

Executive Director,

Retail Energy Services

Edison Electric Institute

Mark Wolfe

Executive Director

Energy Programs Consortium

Lisa Wood

Executive Director

Institute for Electric Efficiency

\section{Facilitators}

U.S. Department of Energy

U.S. Environmental Protection

Agency 


\section{Appendix B: References}

Alliant Energy (2009). Energy Efficiency Cash Rewards: 2009 New Home Construction. <http://www.alliantenergy.com/wcm/groups/wcm internet/documents/contentpage/017136.pdf>

Amann, J.T., and E. Mendelsohn (2005). Comprehensive Commercial Retrofit Programs: A Review of Activity and Opportunities. American Council for an Energy-Efficient Economy. Report no. A052. <http://www.aceee.org/pubs/a052.htm>

Brown, M.H., and B. Conover (2009). Recent Innovations in Financing for Clean Energy. Southwest Energy Efficiency Project.

$<$ http://www.swenergy.org/publications/documents/Recent Innovations in Financing for Clean Energy.pdf>

U.S. Department of Energy [DOE] and U.S. Environmental Protection Agency [EPA] (2010). Database for Incentives and Joint Marketing Exchange. <http://www.energystar.gov/DIME>

U.S. Environmental Protection Agency [EPA] (2005). Clean Energy-Environment Guide to Action. Appendix B: Energy Efficiency Program Resources

<http://www.epa.gov/cleanenergy/energy-programs/state-and-local/state-best-practices.html>

U.S. Environmental Protection Agency [EPA] (2009). Rapid Deployment Energy Efficiency (RDEE) Toolkit: Planning \& Implementation Guides.

$<$ http://www.epa.gov/RDEE/documents/rdee toolkit.pdf>

Fuller, M. (2009). Enabling Investments in Energy Efficiency: A Study of Energy Efficiency Programs That Reduce First-Cost Barriers in the Residential Sector. Prepared for California Institute for Energy and Environment and Efficiency Vermont. <http://uc-

ciee.org/energyeff/documents/resfinancing.pdf>

International Energy Agency (2007). Mind the Gap: Quantifying Principal-Agent Problems in Energy Efficiency.

$<$ <ttp://www.iea.org/Textbase/publications/free new Desc.asp?PUBS ID=1954>

McKinsey \& Company (2009). Unlocking Energy Efficiency in the US Economy.

<http://www.mckinsey.com/clientservice/electricpowernaturalgas/downloads/US energy efficie ncy full report.pdf>

MidAmerican Energy (2009). 2009 Energy Advantage ${ }^{\circledR}$ New Homes Program. <http://www.midamericanenergy.com>

National Action Plan for Energy Efficiency (2006). National Action Plan for Energy Efficiency. $<$ http://www.epa.gov/eeactionplan> 
National Action Plan for Energy Efficiency (2009). Customer Incentives for Energy Efficiency Through Electric and Natural Gas Rate Design. Prepared by William Prindle, ICF International, Inc. <http://www.epa.gov/cleanenergy/documents/rate design.pdf>

North Carolina Solar Center (2009). DSIRE: Database of State Incentives for Renewables and Efficiency. <http://www.dsireusa.org>

Quantum Consulting (2004a). National Energy Efficiency Best Practices Study: Volume NR1Non-Residential Lighting Best Practices Report. Submitted to California Best Practices Project Advisory Committee, Pacific Gas and Electric Company.

<http://www.eebestpractices.com/pdf/BP NR1.pdf>

Quantum Consulting (2004b). National Energy Efficiency Best Practices Study: Volume NR2Non-Residential HVAC Best Practices Report. Submitted to California Best Practices Project Advisory Committee, Pacific Gas and Electric Company.

<http://www.eebestpractices.com/pdf/BP NR2.pdf>

Quantum Consulting (2004c). National Energy Efficiency Best Practices Study: Volume NR5Non-Residential Large Comprehensive Incentive Programs Best Practices Report. Submitted to California Best Practices Project Advisory Committee, Pacific Gas and Electric Company. $<$ http://www.eebestpractices.com/pdf/BP NR5.pdf>

Quantum Consulting (2004d). National Energy Efficiency Best Practices Study: Volume R1Residential Lighting Best Practices Report. Submitted to California Best Practices Project Advisory Committee, Pacific Gas and Electric Company.

<http://www.eebestpractices.com/pdf/BP R1.pdf>

Quantum Consulting (2004e). National Energy Efficiency Best Practices Study: Volume R4Residential Single-Family Comprehensive Weatherization Best Practices Report. Submitted to California Best Practices Project Advisory Committee, Pacific Gas and Electric Company. <http://www.eebestpractices.com/pdf/BP R4.pdf>

York, D., M. Kushler, and P. Witte (2008). Compendium of Champions: Chronicling Exemplary Energy Efficiency Programs From Across the U.S. American Council for an Energy-Efficient Economy. Report no. U081. <http://www.aceee.org/pubs/u081.htm> 

Funding and printing for this report was provided by the U.S. Department of Energy and U.S. Environmental Protection Agency in their capacity as co-sponsors for the National Action Plan for Energy Efficiency. 